\title{
Association of selenium with thyroid volume and echostructure in 35- to 60-year-old French adults
}

\author{
Hélène Derumeaux ${ }^{1}$, Pierre Valeix ${ }^{1,2}$, Katia Castetbon ${ }^{2}$, Michel Bensimon ${ }^{1}$, Marie-Christine Boutron-Ruault ${ }^{1}$, \\ Josiane Arnaud ${ }^{3}$ and Serge Hercberg ${ }^{1,2}$ \\ ${ }^{1}$ UMR INSERM U557/INRA U1125/CNAM, Institut Scientifique et Technique de la Nutrition et de l'Alimentation, CNAM, Paris, France, \\ ${ }^{2}$ Unité de Surveillance et d'Epidémiologie Nutritionnelle, InVS, Paris, France and ${ }^{3}$ Département de Biologie Intégrée, CHU Grenoble, Grenoble, France \\ (Correspondence should be addressed to P Valeix, CNRS, UMR INSERM/INRA/CNAM, Institut Scientifique et Technique de la Nutrition et de \\ l'Alimentation, 2 rue Conté, F-75003 Paris, France; Email: s_valeix@vcnam.cnam.fr)
}

\begin{abstract}
Objective: To investigate the relationship between selenium status, thyroid volume and gland echostructure.

Design: Cross-sectional.

Methods: In 792 men (45-60 years) and 1108 women (35-60 years) from the SU.VI.MAX study, thyroid volume and gland echostructure were determined ultrasonographically. At baseline, thyrotropin, free thyroxine, selenium, zinc, $\alpha$-tocopherol, $\beta$-carotene, retinol, urinary iodine and thiocyanate concentrations were measured. Alcohol consumption, smoking, and menopausal status were assessed by a questionnaire. A stepwise linear and a logistic regression model were used, adjusting for antioxidant vitamins, trace elements status and age.

Results: In women, there was an inverse association between selenium status and thyroid volume $(P=0.003)$. A protective effect of selenium against goiter (odds ratio $(O R)=0.07,95 \%$ confidence interval $(\mathrm{CI})=0.008-0.6)$ and thyroid tissue damage $(\mathrm{OR}=0.2,95 \% \mathrm{CI}=0.06-0.7)$ was observed. There was no evidence of an association between menopausal status and other antioxidant elements, thyroid volume or thyroid hypoechogenicity. Smoking, but not alcohol consumption, was associated with an increased risk of thyroid enlargement in women $(\mathrm{OR}=3.94,95 \% \mathrm{CI}=1.64-9.48)$. No association between thyroid volume, thyroid structure or selenium was found in men.

Conclusion: Our findings suggest that selenium may protect against goiter. Selenium was related to thyroid echostructure, suggesting it may also protect against autoimmune thyroid disease.
\end{abstract}

European Journal of Endocrinology 148 309-315

\section{Introduction}

The first known biological function of selenium, as a component of glutathione peroxidase (GPx), was reported in 1973 (1). The hypothesis that a relationship existed between selenium status and thyroid function was put forward only in the mid-1980s. Three diseases have been associated with severe selenium deficiency: Keshan disease, an endemic juvenile cardiomyopathy, Kashin-Beck disease, an endemic osteoarthropathy, both observed in selenium-deficient zones of China, and myxoedematous endemic cretinism prevalent in goiter-endemic countries with low selenium and GPx serum levels (2). These geographical observations in areas where selenium status is low were reinforced by the identification of the family of the iodothyronine deiodinases, named for their ability to catalyze the activation and inactivation of the thyroid hormones (3). The human thyroid produces hydrogen peroxide $\left(\mathrm{H}_{2} \mathrm{O}_{2}\right)$ for oxidative thyroid hormone synthesis. In myxoedematous endemic cretinism, when selenium deficiency is combined with iodine deficiency, the oxidative challenge to the thyroid results in postnatally altered thyroid tissue (4). To protect itself from oxidative damage, the cytosolic GPx catalyzes the reduction of $\mathrm{H}_{2} \mathrm{O}_{2}$ and organic hydroperoxides. Likewise, prediagnostic low selenium concentrations were associated with higher incidence rates of thyroid cancer in a large-scale case-control Norwegian study (5).

Despite these observations, the advantage of selenium supplementation in patients with borderline selenium intakes has not been conclusively confirmed up to now (6). In combined iodine and selenium deficiency, selenium supplementation is not indicated without prior iodine supplementation $(7,8)$. All these studies were conducted in severely selenium- and iodinedeficient populations. To date, mild to moderate iodine deficiency is still prevalent in most European countries (9). This raises the question of the impact of iodine deficiency, in association with marginally low selenium status, on the epithelial thyroid tissue and on the 
metabolic production of thyroid hormone and cell antioxidant defenses.

The aim of this study was to investigate the relationship between selenium status and thyroid volume (TV), adjusting for antioxidant vitamin and biological trace element status, in a French population sample. A secondary objective was to examine the relationship between selenium status and thyroid structure (nodularity, echogenicity pattern) adjusting for the same factors.

\section{Subjects and methods}

\section{Subjects}

This study was conducted on a subsample of subjects derived from the SU.VI.MAX cohort study. The SU.VI.MAX study is a randomized, double-blind, placebo-controlled, primary-prevention trial designed to test the efficacy of daily supplementation with antioxidant vitamins (vitamin $\mathrm{C}$, vitamin $\mathrm{E}$ and $\beta$-carotene) and minerals (selenium and zinc) in reducing several major health problems in industrialized countries, including cancers and cardiovascular diseases (10). In 1994, 12735 subjects, women aged 35-60, and men aged 45-60 were recruited into the study and followed for 8 years. The SU.VI.MAX study was approved by the Ethical Committee for Biological Studies among Humans (CCPPRB no. 706) of Paris-Cochin, and the Commission Nationale de l'Informatique et des Libertés (CNIL no. 334641). Data on baseline characteristics of the participants suggest that the sample was close to the national population in terms of geographical density and socioeconomic status for the selected age groups (10). The subsample of subjects in the current study was randomly selected from the cohort, 1 year after inclusion, after stratifying on the basis of sex, age and area. Altogether, 3621 subjects were examined for TV through a mobile unit especially equipped with an ultrasonograph. Only subjects having complete data related to age, sex, menopausal status, smoking, alcohol consumption and hormonal and biological status were included in the current analyses. Further exclusion criteria were urinary iodine concentration $\geq 60 \mu \mathrm{g} / 100 \mathrm{ml}$, urinary thiocyanate concentration $\geq 5 \mathrm{mg} / 100 \mathrm{ml}$, subjects treated with thyroid hormones, antithyroid drugs or who were receiving lithium treatment, and subjects with a history of prior thyroid surgery (lobectomy or thyroidectomy). Therefore, from the 3621 subjects originally examined for TV, 1900 subjects, 792 men and 1108 women, were included in the current analyses.

\section{Methods}

This cross-sectional study was performed within the first year of the cohort study. A self-administered general questionnaire was completed by each subject. On this questionnaire, self-reported alcohol consumption, type (beer, wine or liquor), frequency, and amount of drinks consumed during the previous week were recorded. An alcohol index was calculated based on the intake of alcohol in g/day (11). Smoking history was also obtained by questionnaire. Participants were classified as never smoked, former smoker or current smoker. For women, menopausal status was categorized as pre-menopausal vs post-menopausal. One year after inclusion, subjects underwent a clinical examination. Height and weight were measured according to standardized procedures (10). Body mass index (BMI) was calculated as weight $(\mathrm{kg})$ divided by the square of height $\left(\mathrm{m}^{2}\right)$, and body surface area (BSA) according to the following formula BSA $\left(\mathrm{m}^{2}\right)=W^{0.425} \times H^{0.725} \times 71.8 \times 10^{-4}$, where $W$ is the weight in $\mathrm{kg}$ and $H$ the height in $\mathrm{cm}$ (12).

TV TV was estimated by ultrasonography (Sonoline SI-400; Siemens, Erlangen, Germany) using a high frequency 7.5 MHz linear array transducer. The examinations were performed with the patient in a supine position, the neck hyperextended. The lobes were approximated to ovoids and their volume, expressed in $\mathrm{ml}$, was estimated using the formula: volume of one lobe $(\mathrm{ml})=$ length $(\mathrm{mm}) \times$ width $(\mathrm{mm}) \times$ depth $(\mathrm{mm}) \times 0.479$ (13). The total TV was obtained by computing the volumes of both lobes. Nodules and/or cystic areas were included in volume determination whereas the isthmus was not taken into account in volume calculation. This method has been proven to be very accurate (14). All ultrasonographic examinations were performed and interpreted by the same experienced blinded radiologist. A TV $\geq 25 \mathrm{ml}$ in men and $\geq 18 \mathrm{ml}$ in women was defined as goiter (15). Thyroid nodularity (coded in five categories: one, two or three nodules, paucinodularity, multinodularity), nodule size ( $\geq 10 \mathrm{~mm}$ in diameter on ultrasonography), and characteristics (solid and cystic components) were classified qualitatively. Thyroid echogenicity, due to the gland follicular structure, was dichotomized as normal vs diffuse low echogenicity.

Laboratory methods At baseline, both a fasting venous blood sample and morning urine sample were obtained from participants. Serum thyrotropin (TSH) and free thyroxine $\left(\mathrm{FT}_{4}\right)$ were measured in duplicate in the same assay on a fully automated MAGIA 8000 analyzer (Biotrol Diagnostic Company, Chennevièreslès-Louvres, France). Within- and between-run coefficients of variation for $\mathrm{TSH}$ and $\mathrm{FT}_{4}$ were less than $7.6 \%$ over a wide range of concentrations. TSH was measured on a one-step, two-site ultra-sensitive ELISA using two monoclonal antibodies. The detection limit of the TSH assay employed was $0.02 \mathrm{mU} / \mathrm{l}$, and the reference range was $0.12-6.1 \mathrm{mU} / \mathrm{l}$. The TSH standard $80 / 558$ from the WHO was used to calibrate the equipment for the TSH determination. Free $\mathrm{T}_{4}$ was measured by a one-step competitive immunoassay. The reference range used was 9-22 $\mathrm{pmol} / \mathrm{l}$. 
Urinary iodine was measured for all participants in morning urine samples, and concentrations expressed as absolute concentrations $(\mu \mathrm{g} / 100 \mathrm{ml})$ were used as an index of iodine intakes. The urinary iodine, after fully automated wet acid digestion (Technicon Auto Analyzer II, Technicon Instruments Corporation, Turrytown, NY, USA), was measured using a highly sensitive spectrophotometric procedure based on the Sandell-Kolthoff reaction. Urinary thiocyanate concentrations, expressed as absolute concentrations $(\mathrm{mg} / 100 \mathrm{ml})$, were assayed on the same urine sample by means of an automated continuous-flow technique (16). Serum selenium concentrations were determined after sample dilution by electrothermal atomic absorption spectrometry using a Perkin-Elmer 4100 ZL model (Norwalk, CT, USA) fitted with longitudinal Zeeman background correction and an EDL lamp. Serum zinc concentrations were determined by flame atomic absorption spectrometry on a Perkin-Elmer 3110 model. Concentrations of retinol, $\beta$-carotene and $\alpha$-tocopherol were measured by HPLC. Home-prepared pools of sera (vitamins and carotenoids) or commercially available control serum (Trace Element Seronorm; Sero, Billingstad, Norway) were measured during each run in order to ensure precision and accuracy.

Statistical methods Data were compiled on an AlphaVMS system using SAS statistical software (SAS Institute, Version no. 8, Cary, NC, USA). Analyses were carried out separately for men and women because of sex differences in variables such as weight, height, BSA, smoking habits, alcohol consumption and menopausal status.

The association between TV and selenium concentration was estimated by multivariate linear regression analysis. Co-linearity between explanatory variables was assessed by linear regression and estimation of Pearson's correlation coefficient. The regression model and logistic regression model were built up by entering all variables with statistical significance of less than $20 \%$ in univariate analysis. Residuals analysis, the Kolmogorov-Smirnov test and the Durbin-Watson test were used to assess the validity of the normality and independence assumptions. The associations between goiter, echostructure of the thyroid tissue, nodularity and selenium status were estimated by logistic regression analyses. Hosmer and Lemeshow statistics were used to assess goodness of fit of the logistic equation. An association was defined as significant if the 95\% confidence interval (95\% CI) for an odds ratio (OR) did not include unity. Final models, with linear and logistic regression analyses, were selected after manual backward regression. Selection of adjustment variables was made using simple linear regression and chi-square at an $\alpha$ risk of $20 \%$. The threshold for significance was set at 0.05 for multivariate final analyses.

\section{Results}

Distribution of quantitative variables among men and women according to age groups is shown in Table 1 . In women, aging was associated with higher levels of TSH $(P<0.05)$, selenium $(P<0.001), \alpha$-tocopherol $(P<0.001), \beta$-carotene $(P<0.001)$ and retinol $(P<$ $0.05)$. Compared with women aged 45 years and over, men of the same age had significantly higher levels of selenium $(P<0.05)$, zinc $(P<0.001)$ and retinol $(P<0.001)$, and significantly lower levels of $\beta$-carotene $(P<0.001)$. Baseline selenium concentrations ranged from 0.62 to $1.68 \mu \mathrm{mol} / \mathrm{l}$ in men, and from 0.61 to $1.68 \mu \mathrm{mol} / \mathrm{l}$ in women. Mean (interquartile range (IQ)) selenium concentrations were $1.12 \mu \mathrm{mol} / \mathrm{l}$ in men (IQ, 0.99-1.22 $\mu \mathrm{mol} / \mathrm{l}$ ) and $1.08 \mu \mathrm{mol} / \mathrm{l}$ in women (IQ, $0.95-1.18 \mu \mathrm{mol} / \mathrm{l}$ ). The mean (range) TV was $14.8 \mathrm{ml}(3.1-54.5 \mathrm{ml})$ in men, and $9.8 \mathrm{ml}(2.2-47.1 \mathrm{ml})$ in women, while $3.3 \%$ of women and $6.9 \%$ of men had a goiter. The mean (median) urinary iodine concentrations were $9.7 \mu \mathrm{g} / 100 \mathrm{ml}(8.1 \mu \mathrm{g} / 100 \mathrm{ml})$ for the male population, and $9.8 \mu \mathrm{g} / 100 \mathrm{ml}(7.9 \mu \mathrm{g} / 100 \mathrm{ml})$ in women. The proportion of subjects with a urinary iodine concentration $<5.0 \mu \mathrm{g} / 100 \mathrm{ml}$ was $19.3 \%$ among men. The proportion of women with low iodine status varied from $19.3 \%$ in those aged 35-44 years to $22 \%$ in older women $(P=0.09)$.

Parameters estimated from the simple linear regression analysis between TV and explanatory variables are reported in Table 2 and the variables included in the initial model are shown. In univariate analyses, an inverse association existed between selenium and TV, but it was significant only for women $(P=0.0004$ for women, $P=0.15$ for men). In men, BMI $(P<0.0001)$, BSA $(P<0.0001)$, urinary thiocyanate concentration $(P=0.0005)$, smoking status $(P<0.0001)$ and alcohol consumption $(P=0.02)$ were significantly and positively associated with TV. In women, BMI $(P<0.0001)$, BSA $(P<0.0001)$ and smoking status $(P=0.02)$ were positively related to TV. TSH was negatively associated with TV in both men and women $(r=-0.36, P<0.0001$, in men; $r=-0.30, \quad P<0.0001$, in women). Correlations between explanatory variables were positive between urinary thiocyanate and iodine concentrations (men $P<0.0001$, women $P<0.0001)$ and negative between BMI and $\beta$-carotene level (men $P<0.0001$, women $P<0.0001)$. Selenium was positively correlated with urinary iodine $(r=0.13, P=0.0003$, for men; $r=0.08, P=0.006$, for women), $\alpha$-tocopherol $(r=0.07, P=0.04$, for men; $r=0.10, P=0.0007$, for women), retinol $(r=0.18, P<0.0001$, for men; $r=0.21, P<0.0001$, for women), and negatively correlated with urinary thiocyanate $(r=-0.08, P=$ 0.02 , for men; $r=-0.06, P=0.04$, for women). The estimated negative association between selenium and TV remained significant in women $(P=0.003)$ 
Table 1 Clinical and biological characteristics in men and women (mean \pm S.D.) (SU.VI.MAX study, 1994-95).

\begin{tabular}{|c|c|c|c|}
\hline & \multicolumn{2}{|c|}{ Women } & \multirow{2}{*}{$\begin{array}{c}\text { Men } \\
45-60 \text { years }(n=792)\end{array}$} \\
\hline & $35-44$ years $(n=394)$ & $45-60$ years $(n=714)$ & \\
\hline Thyroid volume (ml) & $9.9 \pm 3.7$ & $9.7 \pm 4.0^{\mathrm{a}}$ & $14.8 \pm 6.4^{\mathrm{b}}$ \\
\hline Goiter* (\%) & 3.5 & 3.2 & $6.9^{\mathrm{b}}$ \\
\hline Nodularity (\%) & 12.4 & $19.5^{\mathrm{a}}$ & $12.6^{\mathrm{b}}$ \\
\hline $\mathrm{TSH}(\mathrm{mU} / \mathrm{l})$ & $2.1 \pm 1.4$ & $2.3 \pm 2.6^{a}$ & $1.8 \pm 2.1^{\mathrm{b}}$ \\
\hline $\mathrm{FT}_{4}(\mathrm{pmol} / \mathrm{l})$ & $14.1 \pm 1.9$ & $13.9 \pm 2.1$ & $13.7 \pm 2.0$ \\
\hline Urinary iodine $(\mu \mathrm{g} / 100 \mathrm{ml})$ & $9.5 \pm 5.9$ & $9.9 \pm 7.4$ & $9.7 \pm 6.3$ \\
\hline Urinary thiocyanate $(\mathrm{mg} / 100 \mathrm{ml})$ & $0.8 \pm 0.4$ & $0.7 \pm 0.4$ & $0.8 \pm 0.4^{b}$ \\
\hline Selenium $(\mu \mathrm{mol} / \mathrm{l})$ & $1.1 \pm 0.2$ & $1.1 \pm 0.2^{\mathrm{a}}$ & $1.1 \pm 0.2^{\mathrm{b}}$ \\
\hline Zinc $(\mu \mathrm{mol} / \mathrm{l})$ & $12.9 \pm 1.7$ & $12.8 \pm 1.7$ & $13.5 \pm 1.7^{b}$ \\
\hline$\alpha$-tocopherol $(\mu \mathrm{mol} / \mathrm{l})$ & $29.5 \pm 6.3$ & $31.8 \pm 7.1^{\mathrm{a}}$ & $32.0 \pm 7.1$ \\
\hline$\beta$-carotene $(\mu \mathrm{mol} / \mathrm{l})$ & $0.6 \pm 0.3$ & $0.7 \pm 0.4^{\mathrm{a}}$ & $0.5 \pm 0.3^{\mathrm{b}}$ \\
\hline Retinol $(\mu \mathrm{mol} / \mathrm{l})$ & $2.0 \pm 0.6$ & $2.1 \pm 0.5^{\mathrm{a}}$ & $2.5 \pm 0.6^{b}$ \\
\hline $\mathrm{BSA}\left(\mathrm{m}^{2}\right)$ & $1.6 \pm 0.1$ & $1.6 \pm 0.1^{a}$ & $1.9 \pm 0.1^{\mathrm{b}}$ \\
\hline $\mathrm{BMI}\left(\mathrm{kg} / \mathrm{m}^{2}\right)$ & $22.0 \pm 3.6$ & $23.5 \pm 4.0$ & $25.5 \pm 3.4^{\mathrm{b}}$ \\
\hline Menopausal women (\%) & 0.8 & $38.2^{\mathrm{a}}$ & - \\
\hline \multicolumn{4}{|l|}{ Smoking status } \\
\hline Non-smokers (\%) & 47.5 & $62.3^{\mathrm{a}}$ & $34.3^{\mathrm{b}}$ \\
\hline Former smokers (\%) & 34.8 & 27.0 & 53.2 \\
\hline Current smokers (\%) & 17.8 & 10.6 & 12.5 \\
\hline \multicolumn{4}{|l|}{ Alcohol consumption } \\
\hline Drinkers (\%) & 49.5 & $61.5^{\mathrm{a}}$ & $80.4^{\mathrm{b}}$ \\
\hline g/day & $6.4 \pm 8.5$ & $8.9 \pm 9.8^{a}$ & $25.7 \pm 19.7^{\mathrm{b}}$ \\
\hline
\end{tabular}

* Goiter = thyroid volume $\geq 18 \mathrm{ml}$ in women, $\geq 25 \mathrm{ml}$ in men.

${ }^{\mathrm{a}} P<0.05$ vs women $35-44$ years. ${ }^{\mathrm{b}} P<0.05$ vs women $45-60$ years.

after covariate adjustment for age, BSA, TSH, thiocyanate and smoking status, in the final regression model (Table 3). In women, for a $1 \mu \mathrm{mol} / \mathrm{l}$ selenium concentration increase, TV decreased by $0.18 \mathrm{ml}$ after adjusting for age, TSH, BSA and smoking status. In men, the selenium-TV association was not statistically significant $(P=0.36)$, after adjusting for age, urinary thiocyanate, BSA, TSH and smoking status. The final model explained $15 \%$ of the variance in $\mathrm{TV}$ in women, and $21 \%$ in men.

When the presence or absence of goiter was studied, the final logistic regression model in men retained the following variables (Table 4$)$ : $\mathrm{BSA}(\mathrm{OR}=26.36,95 \% \mathrm{CI}=$ $4.26-163.1)$, TSH $(\mathrm{OR}=0.36,95 \% \mathrm{CI}=0.26-0.49)$ and age $(\mathrm{OR}=0.99,95 \% \mathrm{CI}=0.9-1.06)$. In women, the final model retained the following variables:

Table 2 Simple linear regression analyses of thyroid volume* on determinants in men and women (SU.VI.MAX study, 1994-95).

\begin{tabular}{|c|c|c|c|c|c|c|}
\hline & \multicolumn{4}{|c|}{ Men $(n=792)$} & \multicolumn{2}{|c|}{ Women $(n=1108)$} \\
\hline & $\beta$ & $95 \% \mathrm{Cl}$ & $P$ & $\beta$ & $95 \% \mathrm{Cl}$ & $P$ \\
\hline Age (years) & -0.003 & $-0.009,0.002$ & $0.26^{\star \star}$ & -0.002 & $-0.006,0.001$ & $0.19 * \star$ \\
\hline $\mathrm{TSH}(\mathrm{mU} / \mathrm{l})^{*}$ & -0.188 & $-0.22,-0.15$ & $<0.0001^{* *}$ & -0.15 & $-0.18,-0.12$ & $<0.0001^{* *}$ \\
\hline $\mathrm{FT}_{4}(\mathrm{pmol} / \mathrm{l})$ & 0.027 & $0.014,0.04$ & $<0.0001$ & 0.024 & $0.01,0.03$ & $<0.0001$ \\
\hline Selenium $(\mu \mathrm{mol} / \mathrm{l})$ & -0.12 & $-0.27,0.04$ & $0.15^{\star \star}$ & -0.23 & $-0.36,-0.10$ & 0.0004 ** \\
\hline Urinary iodine $(\mu \mathrm{g} / 100 \mathrm{ml})$ & $7.10^{-4}$ & $-0.004,0.005$ & 0.76 & -0.002 & $-0.006,0.0006$ & $0.11^{* *}$ \\
\hline$\beta$-carotene $(\mu \mathrm{mol} / \mathrm{l})^{*}$ & -0.032 & $-0.08,0.01$ & $0.17^{\star \star}$ & -0.027 & $-0.067,0.01$ & $0.2^{\star \star}$ \\
\hline$\alpha$-tocopherol $(\mu \mathrm{mol} / \mathrm{l})$ & 0.001 & $-0.003,0.005$ & 0.55 & -0.001 & $-0.005,0.002$ & 0.35 \\
\hline Zinc $(\mu \mathrm{mol} / \mathrm{l})$ & -0.013 & $-0.03,0.003$ & $0.11^{\star \star}$ & 0.003 & -0.01 .0 .015 & 0.67 \\
\hline Retinol $(\mu \mathrm{mol} / \mathrm{l})$ & 0.01 & $-0.04,0.06$ & 0.67 & -0.035 & $-0.07,0.005$ & $0.09 * *$ \\
\hline $\mathrm{BMI}\left(\mathrm{kg} / \mathrm{m}^{2}\right)$ & 0.019 & $0.01,0.03$ & $<0.0001^{* *}$ & 0.012 & $0.006,0.02$ & $<0.0001^{\star *}$ \\
\hline $\mathrm{BSA}\left(\mathrm{m}^{2}\right)$ & 0.60 & $0.43,0.77$ & $<0.0001^{* *}$ & 0.52 & $0.37,0.67$ & $<0.0001^{* *}$ \\
\hline Urinary thiocyanate $(\mathrm{mg} / 100 \mathrm{ml})$ * & 0.10 & $0.04,0.16$ & $0.0005^{\star *}$ & 0.034 & $-0.008,0.07$ & $0.11^{\star *}$ \\
\hline Alcohol consumption (g/day) & 0.002 & $2.10^{-4}, 0.003$ & $0.02^{\star \star}$ & 0.001 & $-9.10^{-4}, 0.004$ & 0.25 \\
\hline Current smokers & 0.17 & $0.08,0.25$ & $<0.0001^{\star *}$ & 0.077 & $0.012,0.14$ & $0.02^{\star *}$ \\
\hline Former smokers & 0.037 & $-0.02,0.09$ & 0.19 ** & 0.032 & $-0.016,0.08$ & $0.19 * *$ \\
\hline Menopausal status & - & - & - & -0.044 & $-0.09,0.007$ & $0.09 * *$ \\
\hline Echogenicity & -0.011 & $-0.16,0.13$ & 0.88 & 0.016 & $-0.05,0.09$ & 0.66 \\
\hline Nodules & 0.40 & $0.31,0.49$ & $<0.0001$ & 0.27 & $0.21,0.34$ & $<0.0001$ \\
\hline
\end{tabular}

*A logarithmic transformation was used to normalize the distribution.

** Explanatory variables included in the initial model. 
Table 3 Multiple linear regression analyses of thyroid volume* on determinants in men and women (SU.VI.MAX study, 1994-95).

\begin{tabular}{|c|c|c|c|}
\hline & Variables & $\boldsymbol{\beta}$ & $\boldsymbol{P}$ \\
\hline \multirow[t]{7}{*}{ Men (final model) } & Age (years) & 0.0008 & 0.76 \\
\hline & Thiocyanate $(\mathrm{mg} / 100 \mathrm{ml}) *$ & 0.07 & 0.01 \\
\hline & $\mathrm{BSA}\left(\mathrm{m}^{2}\right)$ & 0.57 & $<0.0001$ \\
\hline & $\mathrm{TSH}(\mathrm{mU} / \mathrm{l}) \star$ & -0.18 & $<0.0001$ \\
\hline & Smoking status & & \\
\hline & Current smokers & 0.14 & 0.001 \\
\hline & Former smokers & 0.06 & 0.04 \\
\hline \multirow{7}{*}{$\begin{array}{l}\text { Women } \\
\quad \text { (final model) }\end{array}$} & Age (years) & -0.001 & 0.36 \\
\hline & $\mathrm{TSH}(\mathrm{mU} / \mathrm{l}) *$ & -0.15 & $<0.0001$ \\
\hline & $\operatorname{BSA}\left(\mathrm{m}^{2}\right)$ & 0.54 & $<0.0001$ \\
\hline & Selenium $(\mu \mathrm{mol} / \mathrm{l})$ & -0.18 & 0.003 \\
\hline & Smoking status & & \\
\hline & Current smokers & 0.09 & 0.006 \\
\hline & Former smokers & 0.02 & 0.32 \\
\hline
\end{tabular}

*A logarithmic transformation was used to normalize the distribution.

selenium $(\mathrm{OR}=0.07,95 \% \mathrm{CI}=0.0008-0.6), \mathrm{TSH}$ $(\mathrm{OR}=0.39,95 \% \mathrm{CI}=0.28-0.55)$, age $(\mathrm{OR}=1.03$, 95\% CI $=0.97-1.09)$, smoking status $(\mathrm{OR}=3.94$, 95\% CI $=1.64-9.48$ for current smokers and $\mathrm{OR}=$ $1.27,95 \% \mathrm{CI}=0.55-2.94$ for former smokers), and $\mathrm{BSA}(\mathrm{OR}=20.75,95 \% \mathrm{CI}=0.55-2.94)$.

Associations between thyroid structure (nodularity and thyroid hypoechogenic pattern) and explanatory variables were also analyzed (Table 5). BSA (OR = $12.7,95 \% \mathrm{CI}=2.7-59.2)$ and $\mathrm{TSH}(\mathrm{OR}=0.5,95 \%$ $\mathrm{CI}=0.4-0.7)$ were significantly associated with an increased nodule risk in men, whereas there was no association between selenium status and nodule occurrence. In women, age $(\mathrm{OR}=1.05,95 \% \quad \mathrm{CI}=$ $1.02-1.08)$ and $\mathrm{TSH}$ level $(\mathrm{OR}=0.8,95 \% \quad \mathrm{CI}=$ 0.6-0.9) were related to nodular goiter incidence but selenium status was not. Associations remained unchanged when the presence or absence of large nodules ( $\geq 10 \mathrm{~mm}$ in diameter) was analyzed.

In men, a thyroid hypoechogenic pattern was associated with smoking status, independently of age (Table 5). Former smokers were at higher risk of hypoechogenicity compared with non-smokers $(\mathrm{OR}=3.1$, $95 \% \quad \mathrm{CI}=1.1-8.3)$ whereas there was no risk associated with current smoking (OR $=0.6,95 \% \mathrm{CI}=$ 0.07-5.0). In women, selenium status was associated with a decreased hypoechogenic thyroid gland risk $(\mathrm{OR}=0.2, \quad 95 \% \mathrm{CI}=0.06-0.7)$, independently of age, TSH and BMI.

\section{Discussion}

In this large cross-sectional study, selenium was inversely related to TV, risk of goiter and hypoechogenicity in women, independently of other known risk factors, i.e. anthropometry, age, menopausal status, smoking habits, alcohol or antioxidants. In men, the odds for goiter occurrence did not reach statistical significance, but lack of power cannot be excluded. It is important to note that these associations have been shown in a population in which mild iodine deficiency is observed (9) and selenium deficiency (defined by selenium concentration $\leq 0.76 \mu \mathrm{mol} / \mathrm{l}(17))$ is rare $(1.1 \%)$. The observed mean ( \pm S.D.) selenium concentration of $1.09 \pm 0.17 \mu \mathrm{mol} / \mathrm{l}$ was within the range of selenium concentrations reported in other French studies $(0.50-1.36 \mu \mathrm{mol} / \mathrm{l})$ (18). As selenium intake is considered to be the major determinant of the serum selenium level (19), the serum selenium concentration is commonly used to estimate selenium intake at a population level. The selenium concentration has been reported to be related to age, physiological status and lifestyle (20), but these factors were controlled in our study.

Experimental and sparse clinical data have suggested that selenium status is involved in thyroid function. The essentiality of selenium for maintaining thyroid hormone economy was later confirmed by the identification of deiodinases as selenoenzymes (21-24). In experimental studies, rats fed a combined selenium- and iodine-deficient diet had significantly increased thyroid weight compared with rats fed an iodine-deficient diet (25). Data in humans are sparse. An observational study in a selenium-deficient population showed decreased selenium levels in a small series of hyperthyroid patients compared with control

Table 4 Logistic regression analyses for risk of goiter in men and women (SU.VI.MAX study, 1994-95).

\begin{tabular}{llcc}
\hline & Variables & OR & 95\% Cl \\
\hline Men (final model) & Age (years) & 0.99 & $0.9,1.06$ \\
& BSA (m²) & 26.36 & $4.26,163.1$ \\
Women (final model) & TSH (mU/l)* & 0.36 & $0.26,0.49$ \\
& Age (years) & 1.03 & $0.97,1.09$ \\
& TSH (mU/l)* & 0.39 & $0.28,0.55$ \\
& Selenium ( $\mu$ mol/l) & 0.07 & $0.008,0.6$ \\
& Smoking status & 3.94 & $1.64,9.48$ \\
& Current vs non-smokers & 1.27 & $0.55,2.94$ \\
& Former vs non-smokers & 20.75 & $2.53,170.4$ \\
\hline
\end{tabular}

*A logarithmic transformation was used to normalize the distribution. 
Table 5 Logistic regression analyses for risk of nodules or hypoechogenic gland tissue in men and women (SU.VI.MAX study, 1994-95).

\begin{tabular}{|c|c|c|c|c|c|}
\hline & \multirow[b]{2}{*}{ Variables } & \multicolumn{2}{|c|}{ Nodules } & \multicolumn{2}{|c|}{$\begin{array}{l}\text { Hypoechogenic } \\
\text { thyroid }\end{array}$} \\
\hline & & OR & $95 \% \mathrm{Cl}$ & OR & $95 \% \mathrm{Cl}$ \\
\hline \multirow[t]{6}{*}{ Men (final model) } & Age (years) & 1.01 & $0.96,1.07$ & 1.06 & $0.9,1.1$ \\
\hline & $\mathrm{BSA}\left(\mathrm{m}^{2}\right)$ & 12.7 & $2.7,59.2$ & - & - \\
\hline & $\mathrm{TSH}(\mathrm{mU} / \mathrm{l})^{*}$ & 0.5 & $0.4,0.7$ & - & - \\
\hline & Smoking status & & & & \\
\hline & Current vs non-smokers & - & - & 0.6 & $0.07,5.0$ \\
\hline & Former vs non-smokers & - & - & 3.1 & $1.1,8.3$ \\
\hline \multirow[t]{4}{*}{ Women (final model) } & Age (years) & 1.05 & $1.02,1.08$ & 1.1 & $1.05,1.1$ \\
\hline & $\mathrm{TSH}\left(\mathrm{mU} / \mathrm{l}^{*}\right.$ & 0.8 & $0.6,0.9$ & 1.3 & $1.03,1.8$ \\
\hline & Selenium ( $\mu \mathrm{mol} / \mathrm{l})$ & - & - & 0.2 & $0.06,0.7$ \\
\hline & BMI $\left(\mathrm{kg} / \mathrm{m}^{2}\right)$ & - & - & 1.1 & $1.05,1.1$ \\
\hline
\end{tabular}

*A logarithmic transformation was used to normalize the distribution.

subjects (26). In Northern Zaire, a selenium-deficient area, 2 months of selenium supplementation without prior iodine supplementation resulted in a marked fall in total $\mathrm{T}_{4}$ levels among schoolchildren, and aggravated hypothyroidism in myxoedematous cretins (7). Our study is the first to underline the involvement of selenium status in the weight of the thyroid gland in a population without selenium deficiency.

An additional original finding of this study is the inverse association between selenium and thyroid hypoechogenicity. Low thyroid echogenicity accompanied lymphocytic infiltration in thyroiditis, and was highly correlated with thyroid autoantibodies in patients with Graves' disease (27). In patients with thyroid hypoechogenicity, lymphocytic infiltration was found in excised thyroid tissue (28). In rats, combined selenium and iodine deficiencies increased necrosis, induced fibrosis and decreased compensatory epithelial proliferation (4). Our findings might therefore be explained by an excess of free radicals, generated by long-term mild iodine deficiency, and unopposed because of sub-optimal selenium status. In a recent study conducted by Gärtner et al. (29) in mildly selenium-deficient women with overt autoimmune thyroiditis and elevated thyroid peroxidase antibodies (TPOAb), selenium supplementation significantly decreased TPOAb concentrations and improved thyroid ultrasound echogenicity. These recent findings should prompt further experimental and clinical studies in order to understand better the relationship between selenium and thyroid-specific autoimmune diseases.

Previous studies had also evaluated the effect of alcohol and smoking on thyroid function. In a recently published study, mean TV was significantly higher in men and women who consumed high quantities of alcohol than in abstainers (30). In our study, an effect of alcohol consumption was confirmed, although it was not statistically significant. Therefore alcohol should be considered as a putative risk factor for high TV. The relationship between smoking and thyroid diseases was recently reviewed (31); current smokers are likely to be at higher risk of goiter than both former and non-smokers, with the latter groups having a risk comparable to each other. In our study, current smoking was also associated with increased TV in men and women, while it was related to goiter risk only in women. Past smoking was related to TV only in men. These observations stress the need for an accurate assessment of smoking in epidemiological studies which evaluate thyroid function and volume, and for further investigation, especially concerning the time lag between smoking cessation and assessment of thyroid function.

In our study, all biological indicators were assessed at inclusion, prior to any antioxidant supplementation, but thyroid ultrasonography was performed 1 year later. The general design of the SU.VI.MAX study did not allow non-blind randomization before the end of the study. However, an effect upon our results through unbalanced groups is unlikely. In addition, a 1 year supplementation probably had little effect on thyroid morphology.

In addition to iodine status, selenium status is likely to be a key factor in the maintenance of normal thyroid morphology and protection of the gland. Since thyroid diseases are very common in Western countries, both epidemiological and experimental studies are needed to evaluate further the effect of the nutritional environment on thyroid diseases.

\section{Acknowledgements}

This study was supported in part by Merck Lipha Santé, a subsidiary of the Merck group, F-69379 Lyon, France. The authors wish to thank E Ferguson (University of Otago, New Zealand) and L Mennen (USEN, InVS), for valuable critical reading of the manuscript. H D was the recipient of a Postgraduate Research Scholarship from the Fondation pour la Recherche Médicale. 


\section{References}

1 Rotruck JT, Pope AL, Ganther HE, Swanson AB, Hafeman DG \& Hoekstra WG. Selenium: biochemical role as a component of glutathione peroxidase. Science 1973179 588-590.

2 Goyens P, Golstein J, Nsombola B, Vis H \& Dumont JE. Selenium deficiency as a possible factor in the pathogenesis of myxoedematous endemic cretinism. Acta Endocrinologica 1987 $114497-502$

3 Behne D \& Kyriakopoulos A. Mammalian selenium-containing proteins. Annual Review of Nutrition 200121 453-473.

4 Contempré B, Dumont JE, Denef JF \& Many MC. Effects of selenium deficiency on thyroid necrosis, fibrosis and proliferation: a possible role in myxoedematous cretinism. European Journal of Endocrinology 1995 133 99-109.

5 Glattre E, Thomassen Y, Thoresen SO, Haldorsen T, Lund-Larsen PG, Theodorsen L et al. Prediagnostic serum selenium in a casecontrol study of thyroid cancer. International Journal of Epidemiology 198918 45-49.

6 Chanoine JP, Nève J, Wu S, Vanderpas J \& Bourdoux P. Selenium decreases thyroglobulin concentrations but does not affect the increased thyroxine-to-triiodothyronine ratio in children with congenital hypothyroidism. Journal of Clinical Endocrinology and Metabolism 200186 1160-1163.

7 Contempré B, Dumont JE, Ngo B, Thilly CH, Diplock AT \& Vanderpas J. Effect of selenium supplementation in hypothyroid subjects of an iodine and selenium deficient area: the possible danger of indiscriminate supplementation of iodine-deficient subjects with selenium. Journal of Clinical Endocrinology and Metabolism 199173 213-215.

8 Vanderpas JB, Contempré B, Duale NL, Deckx H, Bebe N, Longombe AO et al. Selenium deficiency mitigates hypothyroxinemia in iodine-deficient subjects. American Journal of Clinical Nutrition $1993 \mathbf{5 7}$ 271S-275S.

9 Valeix P, Zarebska M, Preziosi P, Galan P, Pelletier B \& Hercberg S. Iodine deficiency in France. Lancet 1999353 1766-1767.

10 Hercberg S, Preziosi P, Briançon S, Galan P, Triol I, Malvy D et al. A primary prevention trial using nutritional doses of antioxidant vitamins and minerals in cardiovascular diseases and cancers in a general population: the SU.VI.MAX study - design, methods, and participant characteristics. Controlled Clinical Trials 199819 $336-351$.

11 Lasfargues G, Vol S, Le Clésiau H, Bedouet M, Hagel L, Constans T et al. Validité d'un autoquestionnaire alimentaire court par comparaison avec un entretien diététique. La Presse Médicale 199019 953-957.

12 Du Bois D \& Du Bois EF. Clinical calorimetry X. A formula to estimate the approximate surface area if height and weight be known. Archives of Internal Medicine 191617 863-871.

13 Brunn J, Block U, Ruf G, Bos I, Kunze WP \& Scriba PC. Volumetrie der schilddrüsenlappen mittels real-time-sonographie. Deutsche Medizinische Wochenschrift 1981106 1338-1340.

14 Berghout A, Wiersinga WM, Smits NJ \& Touber JL. Determinants of thyroid volume as measured by ultrasonography in healthy adults in a non-iodine deficient area. Clinical Endocrinology $198726273-280$.

15 Gutekunst R \& Martin-Reichert TH. Requirements for goiter surveys and the determination of thyroid size. In Iodine Deficiency in Europe. A continuing concern, pp 109-115. Eds F Delange, JT Dunn \& D Glinoer. New York and London: Plenum Press, 1993.

16 Butts WC, Kuehneman M \& Widdowson GM. Automated method for determining serum thiocyanate, to distinguish smokers from nonsmokers. Clinical Chemistry 197420 1344-1348.
17 Nève J. Human selenium supplementation as assessed by changes in blood selenium concentration and glutathione peroxidase activity. Journal of Trace Elements in Medicine and Biology 19959 65-73.

18 Combs GF Jr. Selenium in global food systems. British Journal of Nutrition 200185 517-547.

19 Swanson CA, Longnecker MP, Veillon C, Howe M, Levander OA, Taylor PR et al. Selenium intake, age, gender, and smoking in relation to indices of selenium status of adults residing in a seleniferous area. American Journal of Clinical Nutrition $1990 \mathbf{5 2}$ 858-862.

20 Nève J, Vertongen F, Peretz A \& Carpentier YA. [Usual values of selenium and glutathione peroxidase in a Belgian population] French. Annales de Biologie Clinique 198947 138-143.

21 Berry MJ, Grieco D, Taylor BA, Maia AL, Kieffer JD, Beamer Wet al. Physiological and genetic analyses of inbred mouse strains with a type I iodothyronine $5^{\prime}$ deiodinase deficiency. Journal of Clinical Investigation 199392 1517-1528.

22 Croteau W, Davey JC, Galton VA \& St Germain DL. Cloning of the mammalian type II iodothyronine deiodinase. A selenoprotein differentially expressed and regulated in human and rat brain and other tissues. Journal of Clinical Investigation $1996 \mathbf{9 8}$ 405-417.

23 Salvatore D, Bartha T, Harney JW \& Larsen PR. Molecular biological and biochemical characterization of the human type 2 selenodeiodinase. Endocrinology 1996137 3308-3315.

24 Salvatore D, Low SC, Berry M, Maia AL, Harney JW, Croteau W et al. Type 3 iodothyronine deiodinase: cloning, in vitro expression, and functional analysis of the placental selenoenzyme. Journal of Clinical Investigation 199596 2421-2430.

25 Beckett GJ, Nicol F, Rae PW, Beech S, Guo Y \& Arthur JR. Effects of combined iodine and selenium deficiency on thyroid hormone metabolism in rats. American Journal of Clinical Nutrition 1993 57 240S-243S.

26 Aliciguzel Y, Ozdem SN, Ozdem SS, Karayalcin U, Siedlak SL, Perry G et al. Erythrocyte, plasma, and serum antioxidant activities in untreated toxic multinodular goiter patients. Free Radicals in Biology and Medicine 200130 665-670.

27 Vitti P, Rago T, Mancusi F, Pallini S, Tonacchera M, Santini F et al. Thyroid hypoechogenic pattern at ultrasonography as a tool for predicting recurrence of hyperthyroidism after medical treatment in patients with Graves' disease. Acta Endocrinologica 1992126 $128-131$.

28 Marcocci C, Vitti P, Cetani F, Catalano F, Concetti R \& Pinchera A. Thyroid ultrasonography helps to identify patients with diffuse lymphocytic thyroiditis who are prone to develop hypothyroidism. Journal of Clinical Endocrinology and Metabolism $1991 \quad 72$ 209-213.

29 Gärtner R, Gasnier BCH, Dietrich JW, Krebs B \& Angstwurm MWA. Selenium supplementation in patients with autoimmune thyroiditis decreases thyroid peroxidase antibodies concentrations. Journal of Clinical Endocrinology and Metabolism 2002 87 1687-1691.

30 Knudsen N, Bulow I, Laurberg P, Perrild H, Ovesen L \& Jorgensen T. Alcohol consumption is associated with reduced prevalence of goitre and solitary thyroid nodules. Clinical Endocrinology 2001 $5541-46$.

31 Bartalena L, Bogazzi F, Tanda ML, Manetti L, Dell'Unto E \& Martino E. Cigarette smoking and the thyroid. European Journal of Endocrinology 1995133 507-512.

Received 6 September 2002

Accepted 16 December 2002 